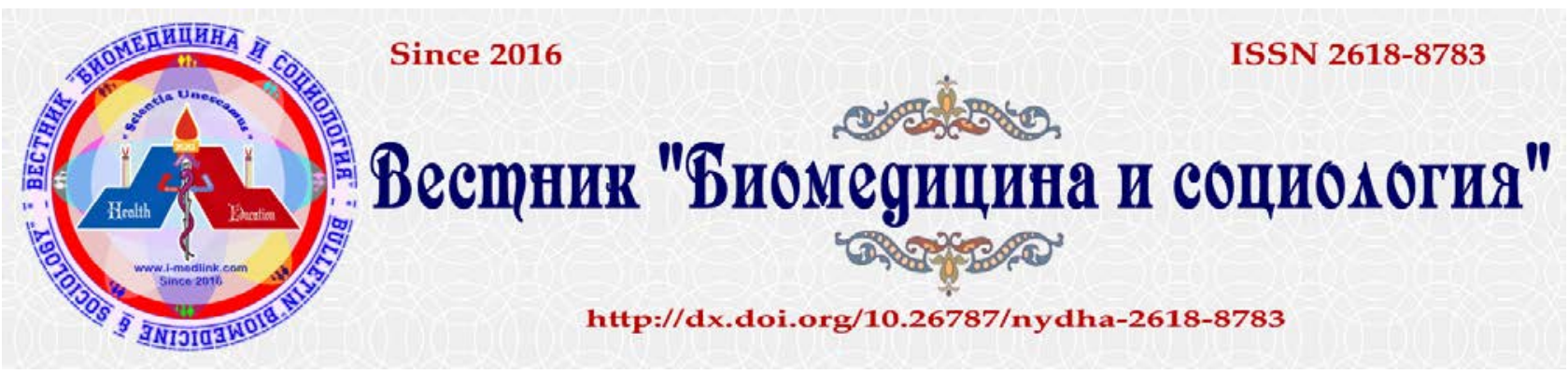

2018, том 3 [2]

http://dx.doi.org/10.26787/nydha-2618-8783-2018-3-2-71-74

ПРОБЛЕМЫ СОВРЕМЕННОЙ МЕДИЦИНЫ В КОНТЕКСТЕ АНТРОПОЛОГИЧЕСКОЙ ЭКОЛОГИИ

\title{
Сапенок О.B.
}

ФГБОУ ВПО «Санкт-Петербургский государственный лесотехнический университет имени С.М. Кирова», г. Санкт-Петербург, Российская Федерация

\begin{abstract}
Аннотация. В статье предпринята попытка выявить некоторые проблемы современной медицины в контексте антропологической экологии. В этом плане важнейшей тенденцией современной медицины можно признать решение проблемы целенаправленного управления поддержанием и улучшением здоровья человека. В контексте антропологической экологии ее философско-мировоззренческими основаниями выступает современная концепция человека как био-социокультурного существа. Подобное понимание человека предполагает трактовку здоровья человека как целостности в единстве соматического и духовного здоровья. В русле этого очевидна необходимость преодоления биологизаторства в теоретической и практической медицине и формирование целостного восприятия больного. Для медицины такой подход должен стать особым мировоззрением, системой ценностей и приоритетов деятельности, ориентированных на оздоровление человеческого бытия в целом.
\end{abstract}

Ключевые слова: антропологическая экология, социальная экология, междисциплинарность, соматическое и духовное здоровье, «оздоровление», биологизаторство, философско-мировоззренческие основания медицины

Как известно, понятие «экология» было введено в науку в 1866 году Э. Геккелем, трактовавшим ее как сферу исследования связей и взаимодействий систем организмов с окружающей их средой безотносительно к природе этих связей. В настоящее время это понятие насчитывает несколько десятков трактовок. Все они могут быть классифицированы на основании трех основных аспектов: экология как раздел биологической науки, экология как междисциплинарный подход к изучению экосистем разного рода, экология как специфическое мировоззрение. В контексте последнего особое значение имеет такое направление как «антропологическая экология».

Одним из первых понятие «экология человека» использовал в своих трудах П. Тейяр де Шарден [3]. В период становления антропологической экологии в русле отечественной традиции ее, как правило, отождествляли с «глобальной экологией» [4]. На основании понимания «глобальной экологии» в качестве самостоятельного раздела экологии, изучающего человека в рамках системы «человек-биосфера», с акцентом на проблемах мировых ресурсов, глобального загрязнения, влияния Космоса на существование Земли в настоящее время подобный подход отвергается. Поскольку экология человека ставит в

\footnotetext{
${ }^{7}$ Материал подготовлен в рамках гранта РФФИ «Феномен квалитативизма в междисциплинарных исследованиях: история и современность» № 18-011-01171.

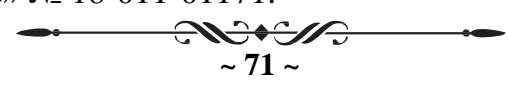

Вестник представлен в научной электронной библиотеке (НЭБ) - головном исполнителе проекта по созданию Российского индекса научного цитирования (РИНЦ)
} 


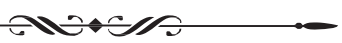

центр исследований многообразие взаимодействий человека с окружающей его средой, прежде всего с социокультурной, ее понимают как подсистему социальной экологии.

Социальная экология в качестве сферы исследовательского интереса была официально признана в первой четверти XX века. Повсеместное распространение и статус научности понятие «социальная экология» получило в конце 60 -х гг. ХХ в., когда резко обострившиеся проблемы взаимодействия общества и природы стали рассматриваться с позиции экологии. Как научная дисциплина социальная экология сформировалась на стыке социологии, экологии, философии и различных областей естествознания, с каждой из которых она тесно взаимодействует.

Предметом антропологической экологии как подсистемы социальной экологии выступают закономерности воздействия человечества на биосферу и те изменения в биосфере, которые, в свою очередь, оказывают влияние на человечество в целом и на каждого человека в отдельности. Исследование единой системы «природа - общество» представителями антропологической экологии предполагает изучение взаимосвязей и взаимодействия между сообществами людей и окружающей их средой и прежде всего изучение влияния деятельности человечества на природные и цивилизационные феномены. Отсюда важнейшей практической задачей данной научной дисциплины признается выработка наиболее эффективных способов и методов воздействия на окружающую среду, которые позволили бы не только предотвратить обострение кризисных ситуаций, но и «оздоровить» биологические и социальные условия жизнедеятельности человека.

В настоящее время исследователи обращают внимание на междисциплинарность антропологической экологии, ее неразрывную связь с естественнонаучным знанием. Понимая антропологическую экологию как междисциплинарную науку о взаимодействии человека со средой обитания, представители указанной тенденции сводят это взаимодействие к адаптации. Соответственно, их исследования в рамках антропологической экологии направлены на изучение приспособительных изменений, происходящих в человеческом организме в зависимости от природных и социальных условий [1]. Указанный подход, обладающий как достоинствами, так и недостатками, на наш взгляд, имеет значение для медицины. С одной стороны, основной акцент в нем делается на характеристиках биологического вида «Ното sapiens» со всеми его биологическими связями (хотя, при этом значение социальных факторов, детерминирующих все опосредованные взаимоотношения человечества с окружающей средой, в определенной степени замалчивается). С другой стороны, представители данного подхода ставят в центр внимания проблему возможностей целенаправленного управления поддержанием и улучшением здоровья человека (что является приоритетом развития современной медицины), совершенствования человека как биологического вида.

Выдвижение в рамках данного подхода в центр внимания исследователей человечества как биологического вида в целом, со всеми его биологическими связями, ведет к затушевыванию роли и значения социокультурных и мировоззренческих факторов, определяющих все опосредованные взаимоотношения человечества с окружающей средой. Сужая предмет антропологической экологии до исследования системы взаимоотношений человека как биологического существа с природной средой, представители данного

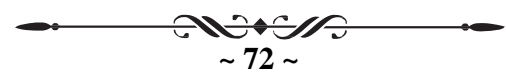

Вестник представлен в научной электронной библиотеке (НЭБ) - головном исполнителе проекта по созданию Российского индекса научного цитирования (РИНЦ) 


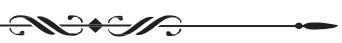

подхода ограничивают его проблематику возможностями целенаправленного управления сохранением и развитием именно соматического здоровья человека, совершенствования человека как биологического вида. Заметим, что, к сожалению, именно в таком русле принято говорить и об экологии образования как о комплексе знаний, навыков и умений, ценностных ориентаций преподавателя и его действий, помогающих сделать учебно-воспитательный процесс оздоравливающим личность, «выработать стратегию создания здорового образа жизни». Таким образом, цель экологии образования ограничивается формированием режима учебно-воспитательного процесса, питания, движения, дыхания, общения обучающих и обучаемых, и последних - между собой.

На наш взгляд, необходимо рациональное преодоление подобного биологизаторства на основе понимания человека как духовного, био-социокультурного существа. Теоретической базой подобного преодоления может стать трактовка человека как творца и творения культуры в философской антропологии. По мнению представителей философской антропологии, человек представляет собой и творение культуры, и творение социума [5]. Социум не только составляет с культурой некую целостность, но и одновременно сохраняет и транслирует ее ценности от поколения к поколению. Незавершенность человека от природы и его открытость миру являются для представителей философской антропологии важнейшими условиями его самосовершенствования, связанными со свободой, творчеством и индивидуальностью человека. Они же выступают импульсом к исследованию различий «мира животных» и «мира человека». Если первый ограничивается средой, окружающей животных, то второй вторичен к окружающей среде и значительно уже ее: человек сам строит и организует этот мир. Среда, непосредственно окружающая человека, принадлежит не природе, а культуре [5].

На основе фундаментальных принципов указанной концепции человека «антропологическую экологию» следует рассматривать в качестве нового междисциплинарного комплексного направления, изучающего разнообразные аспекты взаимодействия человека не только с природной, но и прежде всего с социокультурной средой. В этом плане предметом ее исследования выступают важнейшие социально-культурные, духовные, научные, нравственные и эстетические феномены, которые могут обеспечить выживание человека как био-социокультурного существа, сохранение и оздоровление его телесности и духовности.

Следует подчеркнуть, что преодоление биологизаторства в антропологической экологии необходимо, поскольку в настоящее время становится все более очевидным, что экологический кризис усугубляется кризисом и духовного в человеке, и в глобальном плане всей духовной культуры человечества. Антропологическая экология представляет человека существом, ответственным не только за природу, но и за культуру, за цивилизацию в целом. Масштаб его ответственности как субъекта деятельности, как существа не только планетарного, но и космического определяется местом человека в мире как неотъемлемой составляющей и природы, и цивилизации.

Таким образом, в контексте антропологической экологии важнейшей задачей современной медицины можно признать решение проблемы целенаправленного управления поддержанием и улучшением здоровья человека. Ее философско-мировоззренческими

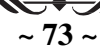$$
\sim 73 \sim
$$ 
основаниями выступает концепция человека как био-социокультурного существа. Подобное понимание человека предполагает трактовку здоровья человека как целостности в единстве соматического и духовного здоровья. В этом плане очевидна необходимость преодоления биологизаторства в теоретической и практической медицине и формирование целостного восприятия больного. Для медицины такой подход в контексте антропологической экологии должен стать особым мировоззрением, системой ценностей и приоритетов деятельности, ориентированных на оздоровление человеческого бытия в целом.

\title{
БИБЛИОГРАФИЧЕСКИЙ СПИСОК
}

1. Гора В.П. Экология человека: учебное пособие для вузов /2-е изд., перераб. и доп. - М.: Дрофа, 2007. 540 c.

2. Реймерс Н.Ф. Природопользование. - М.: Мысль, 1990. - 637 с.

3. Тейяр де Шарден П. Феномен человека: Сб. очерков и эссе: Пер. с фр. / П. Тейяр де Шарден / Сост. и предисл. В.Ю. Кузнецов. - М.: ООО «Издательство АСТ», 2002. - 553 с.

4. Шварц С. С. Экологические закономерности эволюции. М.: «Наука, 1980.- 638 с.

5. Rothacker E. Zur Genealogie des menschlichen Bewusstseins. Bonn, 1966. - 384 p.

\section{PROBLEMS OF MODERN MEDICINE IN THE CONTEXT OF ANTHROPOLOGICAL ECOLOGY} Sapenok O.V.

St.Petersburg state forest technical university, Saint Petersburg, Russian Federation

\begin{abstract}
Annotation. The article attempts to identify some problems of modern medicine in the context of anthropological ecology. In this regard, the most important trend of modern medicine can be recognized as a solution to the problem of purposeful management of the maintenance and improvement of human health. In the context of anthropological ecology, the modern concept of man as a bio-socio-cultural being acts as its philosophical and ideological basis. Such an understanding of human health involves the interpretation of human health as a whole in the unity of somatic and spiritual health. In line with this, the need to overcome biologization in theoretical and practical medicine and the formation of a holistic perception of the patient is obvious. For medicine, this approach should be a special worldview, a system of values and priorities of activities aimed at improving the human being as a whole. Key word: anthropological ecology, social ecology, interdisciplinarity, physical and spiritual health, «recovery», biologicalactive, the philosophical bases of medicine.
\end{abstract}

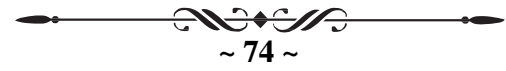

